\title{
Diversity of Geophilic Dermatophytes Species in the Soils of Iran; The Significant Preponderance of Nannizzia fulva
}

\author{
Simin Taghipour ${ }^{1}$, Mahdi Abastabar ${ }^{2}$, Fahimeh Piri ${ }^{3}$, Elham Aboualigalehdari ${ }^{4}$, Mohammad Reza Jabbari ${ }^{2}$, \\ Hossein Zarrinfar ${ }^{5}$ (), Sadegh Nouripour-Sisakht ${ }^{6}$, Rasoul Mohammadi ${ }^{7}$, Bahram Ahmadi ${ }^{8}$, Saham Ansari ${ }^{9}$,

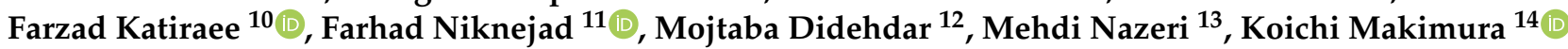 \\ and Ali Rezaei-Matehkolaei $3,4, * \mathbb{B}$
}

Citation: Taghipour, S.; Abastabar, M. Piri, F.; Aboualigalehdari, E.; Jabbari, M.R.; Zarrinfar, H.; Nouripour-Sisakht, S.; Mohammadi, R.; Ahmadi, B.; Ansari, S.; et al. Diversity of Geophilic Dermatophytes Species in the Soils of Iran; The Significant Preponderance of Nannizzia fulva. J. Fungi 2021, 7, 345. https://doi.org/10.3390/jof7050345

Academic Editors: Sophie Brun,

Bernard R. Mignon

and Jean-Philippe Bouchara

Received: 24 March 2021

Accepted: 26 April 2021

Published: 28 April 2021

Publisher's Note: MDPI stays neutral with regard to jurisdictional claims in published maps and institutional affiliations.

Copyright: (c) 2021 by the authors. Licensee MDPI, Basel, Switzerland. This article is an open access article distributed under the terms and conditions of the Creative Commons Attribution (CC BY) license (https:// creativecommons.org/licenses/by/ $4.0 /)$.
1 Department of Medical Parasitology and Mycology, Faculty of Medicine, Shahrekord University of Medical Sciences, Shahrekord 88157-13471, Iran; simintaghipoor@yahoo.com

2 Invasive Fungi Research Center, Department of Medical Mycology and Parasitology, School of Medicine, Mazandaran University of Medical Sciences, Sari 48157-33971, Iran; mabastabar@gmail.com (M.A.); mjpezeshk2@gmail.com (M.R.J.)

3 Infectious and Tropical Diseases Research Center, Health Research Institute, Ahvaz Jundishapur University of Medical Sciences, Ahvaz 61357-15794, Iran; piri.fahimeh@gmail.com

4 Department of Medical Mycology, School of Medicine, Ahvaz Jundishapur University of Medical Sciences, Ahvaz 61357-15794, Iran; aboualielham@gmail.com

5 Allergy Research Center, Mashhad University of Medical Sciences, Mashhad 91766-99199, Iran; h.zarrin@gmail.com

6 Medicinal Plants Research Center, Yasuj University of Medical Sciences, Yasuj 75919-94799, Iran; nooripoor8561@gmail.com

7 Department of Medical Parasitology and Mycology, School of Medicine, Infectious Diseases and Tropical Medicine Research Center, Isfahan University of Medical Sciences, Isfahan 81746-73461, Iran; dr.rasoul_mohammadi@yahoo.com

8 Department of Medical Laboratory Sciences, Faculty of Paramedical, Bushehr University of Medical Sciences, Bushehr 75187-59577, Iran; bahram.ahmadi.fahlyan@gmail.com

9 Department of Medical Parasitology and Mycology, School of Medicine, Shahid Beheshti University of Medical Sciences, Tehran 19857-17443, Iran; samansari1988@yahoo.com

10 Department of Pathobiology, Faculty of Veterinary Medicine, University of Tabriz, Tabriz 51666-16471, Iran; katiraee_f@yahoo.com

11 Laboratory Sciences Research Center, Golestan University of Medical Sciences, Gorgan 49189-36316, Iran; fniknezhad@yahoo.com

12 Department of Medical Mycology and Parasitology, School of Medicine, Arak University of Medical Sciences, Arak 63417-38481, Iran; didehdar_m@yahoo.com

13 Infectious Diseases Research Center, Kashan University of Medical Sciences, Kashan 87159-73474, Iran; mehdinazeri@yahoo.com

14 Laboratory of Medical Mycology, Graduate School of Medicine, Teikyo University, Tokyo 173-8605, Japan; makimura@med.teikyo-u.ac.jp

* Correspondence: a.r.matehkolaie@gmail.com; Tel.: +98-91-2711-2573; Fax: +98-61-3333-2036

Abstract: A molecular epidemiology study was conducted between 2016 and 2017 by a network of collaborators from 12 provinces in the Islamic Republic of Iran. A total of 1484 soil samples from different habitats were screened for the presence of dermatophytes by using the hair baiting technique. The primary identification of isolates was carried out by amplification and MvaI restriction fragment length polymorphism (RFLP) of the internal transcribed spacers regions of ribosomal DNA (ITS-rDNA). The identifications, especially in the cases of isolates with unknown RFLP patterns, were confirmed by sequencing of the ITS-rDNA region. As a result, 256 isolates were recovered. The isolation rate was higher in soils with $\mathrm{pH}$ range 7.1-8.0, collected from animal habitats $(n=78$; $34 \%)$ and parks and gardens $(n=75 ; 32 \%)$, geographically from Mazandaran Province $(n=115$; $49.5 \%)$ and seasonally in the spring $(n=129 ; 50.4 \%)$, all of which were statistically significant $(p<0.05)$. The dermatophytes comprising five species of the two genera, viz., Nannizzia fulva $(n=214), N$. gypsea $(n=34)$, Arthroderma quadrifidum $(n=5)$, . gertleri $(n=2)$ and A. tuberculatum $(n=1)$, were isolated. The geophilic dermatophytes occurred in various soils from different parts of Iran; however, surprisingly, $N$. fulva emerged as the dominant species, outnumbering the common 
geophilic species of N. gypsea. For the definitive identification of soil inhabitant dermatophytes, DNA-based identification is strongly recommended.

Keywords: geophilic dermatophytes; Nannizzia fulva; Arthroderma; ITS sequencing; Iran

\section{Introduction}

It is known that soil is a possible reservoir of some fungal pathogens, causing cutaneous infections in humans and animals, among which dermatophytes are the most important [1,2]. Dermatophytes are a group of filamentous fungi and encompass the seven genera of Trichophyton, Microsporum, Epidermophyton, Nannizzia, Arthroderma, Lophophyton and Paraphyton [3]. The dermatophytes species are of veterinary and public health significance, because they can invade the stratum corneum of the skin and its appendages such as nails and hair in both humans and animals, causing infections medically termed as dermatophytosis (ringworm) [4]. Ecologically, most dermatophyte species are anthropophilic (human-adapted) or zoophilic (related to animal dwellings), while the third group (geophilic) resides in soils and are termed geophilic. The occurrence of infections by geophilic dermatophytes is low but continuous, and their ability to cause human and animal infections is also well-known around the world, thus drawing the attention of medical and veterinary mycologists [5,6]. In public places such as parks and gardens and, also, in animal residences, the soil is continuously manipulated by humans and animals. Then, it is logical to imagine that organic keratinous debris are constantly mixed with the soil, and that such soils, if contaminated with pathogenic keratinophilic fungi, may infect humans and animals [7]. The innovation of the hair bait technique by Vanbreuseghem [8] in 1952, on the one hand, and on the other hand, the application of molecular approaches have increased our understanding of the diversity and ecology of soil fungi [9,10]. A study on the occurrence of keratinophilic fungi, including dermatophytes in the soils of Iran, was launched in 2002 by Shadzi et al. in Isfahan [11]. Since then, few investigations have been performed on the dermatophytes mycoflora of the soil [10,12-14], but the diversity of dermatophyte species in soils from most parts of the country remains largely unknown. The Islamic Republic of Iran, commonly known as Iran, is geographically located in West Asia. It is the second-largest country in the Middle East and 17th largest in the world, covering 636,372 square miles. The country is characterized by 11 of the 13 world's climates, ranging from arid and semi-arid to a subtropical climate, and has four distinct seasons spread throughout the year. However, not all parts of the country experience all four seasons: (What Type of Climate Does Iran Have? Accessed 20 June 2019, $<$ https:/ / www.worldatlas.com/articles/what-type-of-climate-does-iran-have.html>). In this study, by using sequence-based methods of PCR-RFLP and PCR sequencing, we aimed to characterize the species composition and distribution profile of geophilic dermatophytes in soils from 12 different provinces of Iran, with respect to the seasonal status and ecological niche.

\section{Methods}

\subsection{Locations and Selection of Sites for Collection of Soil Samples}

A total of 1484 soil samples were collected during November 2016 to the end of September 2017 from different habitats in 12 governorates of Iran. The sampling sites were selected on the basis of the likely presence of soil with keratin residues from humans and animals, e.g., garden and park, mountain, animal habitat, roadside, home range, riverside and schools. A small amount of soil sample (10 g) was transferred to a 50-mL falcon tube containing 100-mL double-distilled water (ddw), and the mixture was shortly agitated then allowed to stand for about $30 \mathrm{~min}$. A pH electrode (Knick Portamess ${ }^{\circledR} 911 \mathrm{pH}$ meter, Berlin, Germany) was inserted into the solution, and the acidity was read. 


\subsection{Fungal Isolation and Purification}

Around 100-200 g of soil from the superficial layer at a depth not exceeding $5 \mathrm{~cm}$ was picked up with a plastic disposable spoon and placed in a single-use plastic bag. For fungal isolation by the Vanbreuseghem technique [8], a sterile Petri dish was filled with the soil sample; then, fragments of sterilized human (girl) hairs were sprinkled over the soil for baiting. The hair-baited soil dishes were moistened with sterile distilled water supplemented with 0.5-mg/mL cycloheximide (Sigma-Aldrich Co, Ltd., St. Louis, MO, USA) and 5-mg/mL chloramphenicol (Sigma-Aldrich Co, Ltd., St. Louis, MO, USA) incubated at $28{ }^{\circ} \mathrm{C}$ and checked daily for the fungal growth for up to 8 weeks. Fungal growths appearing on baited hairs were stained with lactophenol aniline blue solution and examined microscopically. In the case of the presence of fungal elements characteristic for a dermatophyte growth, the invaded hairs were inoculated with Mycosel agar (BD Diagnostics, Becton Drive, Franklin Lakes, NJ, USA) to get a pure culture. Each grown colony was microscopically checked, and the pure isolate was preliminarily recognized by phenotypic characteristics at the genus/species level.

\subsection{Molecular Identification}

In this study, for preliminary molecular screening/identification of the isolates, we used amplification and the MvaI restriction fragment length polymorphism (RFLP) of the internal transcribed spacer (ITS) regions of the rDNA (ITS-rDNA). Briefly, the DNA was mechanically extracted by using the method described previously [10]. Then, amplification of the ITS-rDNA regions was accomplished by using the primer pair ITS1 and ITS4 [15]. The amplified products were then subjected to digestion with a MvaI restriction enzyme following the manufacture's instruction (Thermo Fisher Scientific, Waltham, MA, USA). The fractionized products were separated through agarose gel (2\%) electrophoresis, and each isolate was identified on the species level via a size comparison of the obtained bands with those reported in a previous study [16].

\subsection{Sequencing}

To corroborate the identification made by the ITS-RFLP findings, and also, to distinguish some isolates whose RFLP patterns were unknown, 86 isolates from culture-positive samples were subjected to sequencing of the ITS r-DNA regions as a gold standard. Briefly, the ITS rDNA regions were amplified and sequenced with the ITS1/ITS4 primer pair [15] in an ABI Prism ${ }^{\mathrm{TM}} 3730$ genetic analyzer (Applied Biosystems, Foster City, CA, USA). The obtained sequences were then edited and blasted against known sequences in the validated Dermatophyte Database of the Westerdijk Fungal Biodiversity Institute (Utrecht, The Netherlands) to provide species identification. All generated sequences in the study were submitted to GenBank.

\subsection{Statistical Analysis}

The effects of the variables such as soil habitat, location of isolation, soil acidity $(\mathrm{pH})$ and season of sampling on the isolation rate and type of isolated species were statistically examined using the chi-square $\left(\mathrm{x}^{2}\right)$ test with SPSS software version 21 (IBM, Armonk, NY, USA).

\section{Results}

\subsection{Number of Positive Soil Samples Regarding to Soil pH, Habitat, Geography and Season}

In total, in $256(17.3 \%)$ cases, a dermatophyte isolate was recovered from the soil samples. In Table 1 and Figure 1, the frequencies of the isolates regarding different soil habitats, geographic locations, seasons and soil $\mathrm{pH}$ were illustrated. According to Table 1, the best isolation rate was accomplished with the soils of animal habitats $(34 \%)$, parks and gardens $(32 \%)$. Seasonally, the highest isolation rate $(n=129 ; 50.4 \%)$ was achieved in the spring and, geographically, from Mazandaran $(n=115 ; 44.9 \%)$ Province. Looking at the soil $\mathrm{pH}$, the isolation rate of the dermatophytes significantly differed, and most of the isolates 
were recovered from soils with the acidity range 7.1-8.0 $(p<0.05)$. Likewise, the soils from Mazandaran and Khuzestan had, respectively, the highest (50.7\%) and the lowest (6.5\%) positivity rates of isolation, which were statistically meaningful $(p<0.05)$.

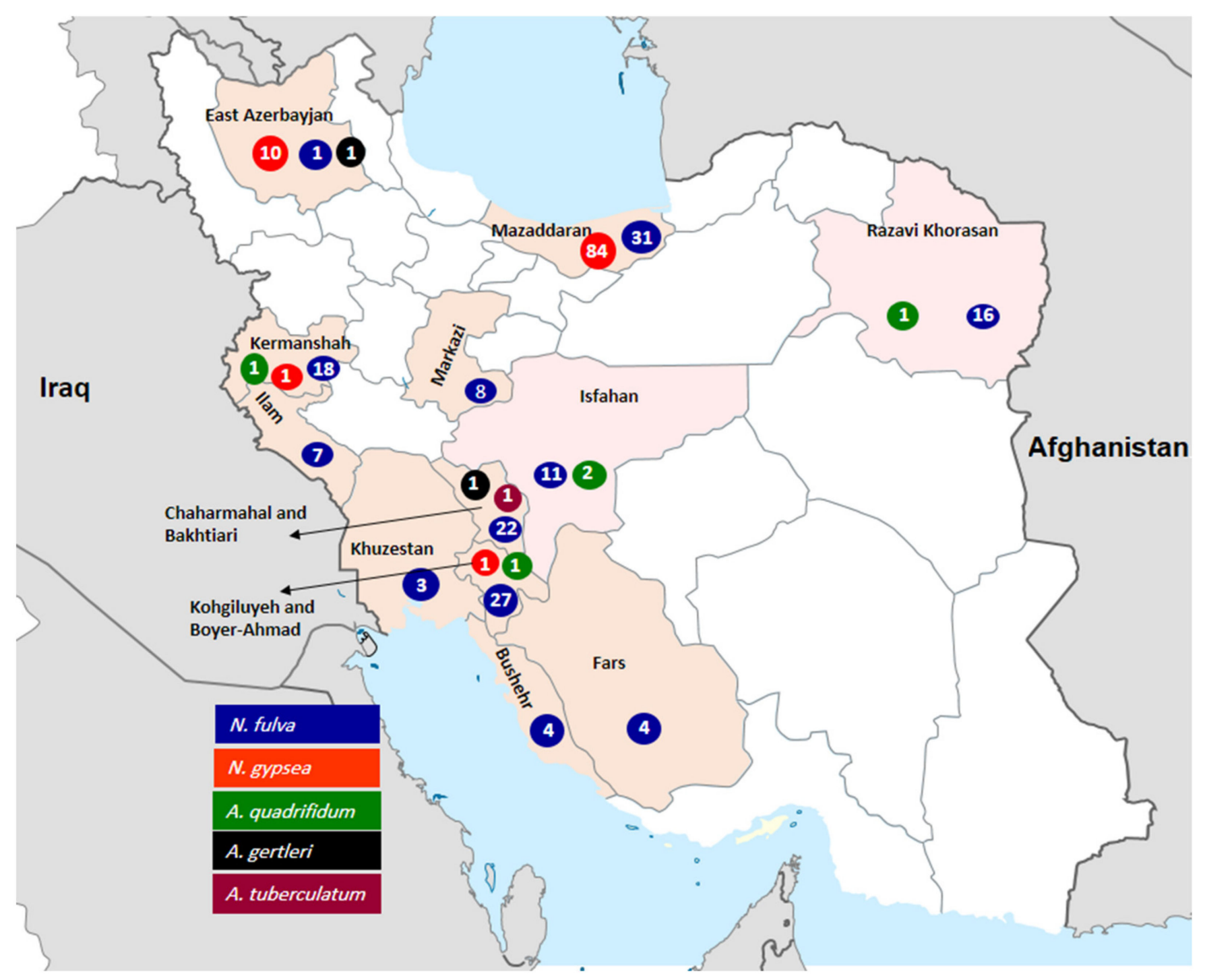

Figure 1. Frequency and distribution of isolated geophilic species according to the geographic location.

\subsection{Molecular Identification of Isolates}

In Table 2 and Figure 2, the results of the molecular identification are summarized. The amplification of ITS-rDNA in all isolates yielded products ranging from 652 to $677 \mathrm{bp}$ in size. In the primary screening of isolates by the ITS-RFLP profiles, $214(83.6 \%)$ and $34(13.3 \%)$ isolates were, respectively, identified as N. fulva and N. gypsea, whereas eight isolates created new and unknown RFLP patterns (Figure 2). The sequencing of the representative isolates confirmed the identification of $N$. gypsea and $N$. fulva isolates and revealed the identity of eight unknown strains as A. quadrifidum $(n=5)$, A. gertleri $(n=2)$ and A. tuberculatum $(n=1)$. Nannizzia fulva was the predominant species isolated from all the provinces. The new sequences generated in this study were deposited in GenBank (Table 2). The results of similar studies from different countries are summarized in in Table 3. 
Table 1. Distribution of the geophilic isolates regarding the sources and $\mathrm{pH}$ of the soils.

\begin{tabular}{|c|c|c|c|c|c|c|c|c|c|c|c|c|c|c|}
\hline \multirow[b]{2}{*}{ Species } & \multicolumn{6}{|c|}{ Soil Source } & \multicolumn{3}{|c|}{ pH Range } & \multicolumn{4}{|c|}{ Season } & \multirow[t]{2}{*}{ Tota } \\
\hline & $\begin{array}{c}\text { Animal } \\
\text { Habitats }\end{array}$ & $\begin{array}{l}\text { Park and } \\
\text { Garden }\end{array}$ & $\begin{array}{l}\text { School and } \\
\text { University }\end{array}$ & $\begin{array}{l}\text { Home } \\
\text { Range }\end{array}$ & Riverside & $\begin{array}{l}\text { Mountain and } \\
\text { Roadside }\end{array}$ & $6-7$ & $7.1-8$ & $8.1-9$ & Spring & Summer & Autumn & Winter & \\
\hline N. gypsea & 4 & 4 & 17 & 9 & - & - & - & 28 & 6 & 29 & 1 & 4 & 0 & 34 \\
\hline A. quadrifidum & 3 & 2 & - & - & - & - & - & 4 & 1 & & & & & 5 \\
\hline A. tuberculatum & - & 1 & - & - & - & - & - & - & 1 & 1 & 0 & 0 & 0 & 1 \\
\hline Total & 87 & 82 & 44 & 30 & 4 & 9 & 2 & 148 & 106 & 129 & 67 & 40 & 24 & 256 \\
\hline
\end{tabular}

Table 2. ITS-RFLP profiles of the keratinophilic fungi identified in this study.

\begin{tabular}{|c|c|c|c|}
\hline Species & Size of ITS-rDNA & Size of Digested ITS-rDNA & GenBank Accession No. \\
\hline N. fulva & 652 & $322,147,112,52,19$ & MG572978-MG573055 \\
\hline N. gypsea & 666 & $289,179,146,33,19$ & MG573057-MG573059 \\
\hline A. gertleri & $655-656$ & $268,212,117,59$ & MG561646-MG561647 \\
\hline A. quadrifidum & 661 & $268,196,121,76$ & MG561441-MG561442 \\
\hline A. tuberculatum & 677 & $198,175,114,106,62,22$ & MT573332 \\
\hline
\end{tabular}

Table 3. A summary on the occurrence of dermatophytes in the soils from various countries.

\begin{tabular}{|c|c|c|c|c|c|c|}
\hline Reference & Country (Year) & $\begin{array}{l}\text { Soil } \mathrm{pH} \text { with the } \\
\text { Highest Isolation }\end{array}$ & $\begin{array}{c}\text { Source with the } \\
\text { Most Positivity Rate }\end{array}$ & $\begin{array}{l}\text { Identification } \\
\text { Method }\end{array}$ & Diversity of Recovered Species & $\begin{array}{l}\text { The Dominant } \\
\text { Isolated Species }\end{array}$ \\
\hline Pakshir et al. [14] & $\operatorname{Iran}(2013)$ & $7.0-9.0$ & Parks & ITS sequencing & N. gypsea, N. fulva & N. gypsea \\
\hline Dehghan et al. [12] & Iran (2019) & ND * & Parks & ITS sequencing & N. fulva, T. mentagrophytes & N. fulva \\
\hline Balajee et al. [1] & India (1997) & $7.0-7.5$ & Garden and park & Mating test & N. gypsea, N. fulva, T. mentagrophytes & N. gypsea \\
\hline
\end{tabular}


Table 3. Cont

\begin{tabular}{|c|c|c|c|c|c|c|}
\hline Reference & Country (Year) & $\begin{array}{l}\text { Soil pH with the } \\
\text { Highest Isolation }\end{array}$ & $\begin{array}{l}\text { Source with the } \\
\text { Most Positivity Rate }\end{array}$ & $\begin{array}{l}\text { Identification } \\
\text { Method }\end{array}$ & Diversity of Recovered Species & $\begin{array}{l}\text { The Dominant } \\
\text { Isolated Species }\end{array}$ \\
\hline Sharma et al. [17] & India (2008) & ND & Public places & ITS sequencing & N. persicolor, N. fulva, N. gypsea & N. persicolor \\
\hline Giugnani et al. [18] & USA (2020) & ND & Cultivated fields & Morphology & N. fulva, N. gypsea & N. fulva \\
\hline Gugnani et al. [19] & St. Kitts and Nevis (2012) & ND & Under trees & Morphology & N. gypsea, N. fulva & N. fulva \\
\hline Taha et al. [20] & Egypt (2018) & ND & Roadside & ITS sequencing & $\begin{array}{l}\text { N. gypsea, T. mentagrophytes, N. fulva, } \\
\text { T. benhamiae, A. multifidum }\end{array}$ & N. gypsea \\
\hline Pontes et al. [21] & Brazil (2008) & $7.0-8.0$ & Slum & Morphology & $\begin{array}{l}\text { T. terrestre, T. mentagrophytes, T. verrucosum, } \\
\text { T. tonsurans, N. gypsea }\end{array}$ & T. mentagrophytes \\
\hline Jain et al. [2] & India (2011) & $7.0-8.0$ & Roadside and garden & Morphology & $\begin{array}{l}\text { T. rubrum, T. simii, T. mentagrophytes, } \\
\text { T. terrestre, T. verrucosum, N. fulva, M. canis, } \\
\text { M. audouinii, E. floccosum }\end{array}$ & T. mentagrophytes \\
\hline Kačinová et al. [23] & Austria (2013) & $7.0-8.0$ & Animal habitats & Morphology & A. uncinatum (T. ajelloi), N. gypsea, T. terrestre & A. uncinatum \\
\hline Javoreková et al. [24] & Slovakia (2012) & $5.0-6.0$ & National parks & Morphology & $\begin{array}{l}\text { A. uncinatum, A. multifidum, } \\
\text { Microsporum sp., T. terrestre }\end{array}$ & A. uncinatum \\
\hline Ciesielska et al. [22] & Poland (2014) & $3.0-5.0$ & ND & ITS-RFLP & A. uncinatum & A. uncinatum \\
\hline Caretta et al. [21] & Italy (1992) & ND & Parks & Morphology & A. uncinatum, N. gypsea & A. uncinatum \\
\hline Bohacz et al. [25] & Poland (2012) & $3.4-4.4$ & Arable fields & Morphology & A. uncinatum & A. uncinatum \\
\hline
\end{tabular}

* ND = not determined. 


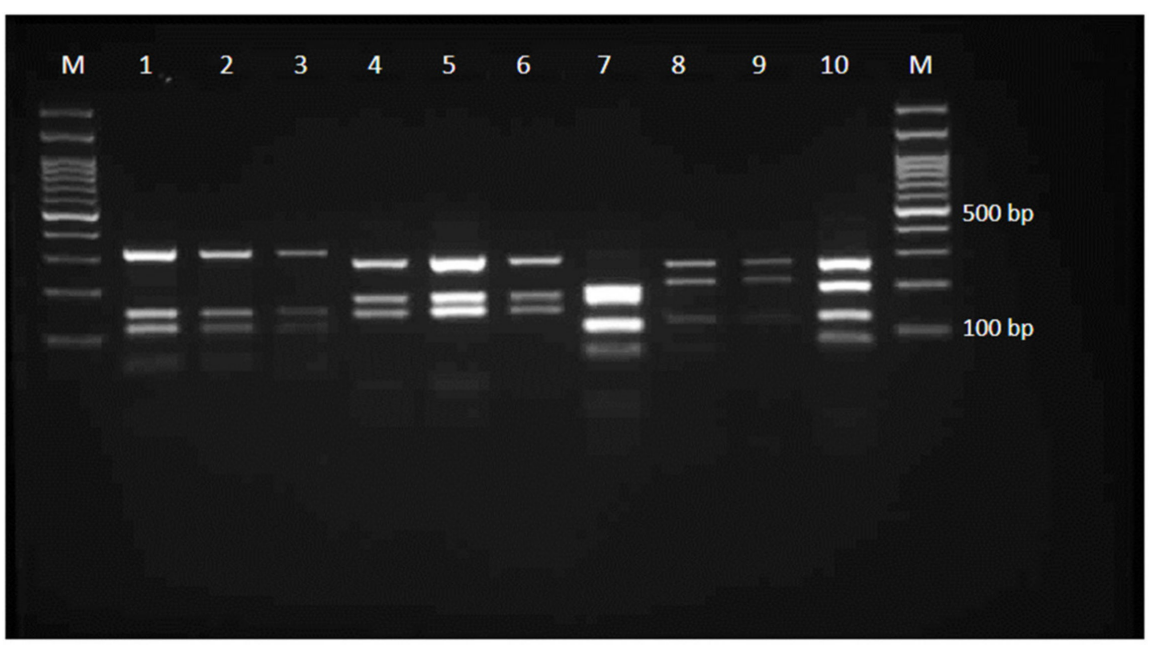

Figure 2. Electrophoretic profiles obtained with representative dermatophyte isolates for ITS-rDNA digested with MvaI. Lanes 1-3 =N. fulva, 4-6 = N. gypsea, $7=$ A. tuberculatum, $8-9=$ A. gertleri and $10=$ A. quadrifidum .

\section{Discussion}

Compared to some previous reports from Iran, narrating the narrow diversity of dermatophytes species in the soils [10,12-14], in this assessment, the spectrum of geophilic dermatophytes recovered from the soils has extended to five species, including three new species that have not been reported yet. In our recent study from Khuzestan, southwest of Iran, we hypothesized that $N$. fulva is most likely the main dermatophyte resident in the soils of Iran, and the application of sequence-based methods will clarify this issue [10]. The extensive isolation of $N$. fulva from the soils of 11 additional provinces in the current study confirmed our hypothesis and highlighted the fact that many geophilic soil/clinical isolates formerly reported as $N$. gypsea, on the sole basis of morphological criteria, may actually be other morphological closely related species. The best and the main explanation we have for why N. fulva was not reported in the earlier surveys of geophilic dermatophytes in Iran is that the species may has often been misidentified as N. gypsea. From the classical circumscriptions of the N. gypsea (formerly Microsporum gypseum) complex, it is impossible to distinguish $N$. gypsea, N. fulva and N. incurvata species solely based on their morphological features. Currently, the best strategy to discriminate these taxa is sequence-based methods, i.e., ITS-rDNA RFLP and sequencing [10], as confirmed by the present results. However, the ITS-rDNA restriction banding patterns are not characteristic for all dermatophytes, especially when some species have similar or undescribed restriction profiles. In consensus with this, and as inferred from Figure 2, the three new species detected in this national investigation, i.e., A. tuberculatum, A. gertleri and A. quadrifidum, produced ITS-rDNA restriction profiles that were unknown so far. Therefore, it is a matter of debate whether N. fulva and the other, less frequent species isolated in this study are truly rare or misidentified, and therefore, their true incidence is underestimated. A few investigations on geophilic dermatophytes that have attempted to discriminate between members of the $N$. gypsea complex have also supported this issue $[12,17,19,20]$. In the study of Sharma et al. (2008) on dermatophytes isolated from the soil of an area in Central India by ITS-RFLP and sequencing, $73 \%$ of isolates were identified as N. persicolor, followed by N. fulva (20\%) and N. gypsea $(7 \%)$ [17]. That finding was achieved even though N. persicolor had never been recorded in India until then. In the survey of keratinophilic fungi in soils of St. Kitts and Nevis, Gugnani et al. using morphological methods found a significant percentage of N. fulva (46\%), in addition to N. gypsea (54\%) [19]. Taha et al., in a sequence-based survey on different places in the Sharkia Governorate, Egypt, found T. mentagrophytes, N. fulva, T. benhamiae and A. multifidum, along with N. gypsea (the dominant species), as the spectrum of soil-inhabitant dermatophytes [20]. In Iran, three similar screenings have 
recently been carried out, all of which were based on the molecular approaches [10,12,14]. In investigations from Ahvaz, southwest, and Isfahan, in the center of Iran, N. fulva was the only recovered species, and all the soil isolates morphologically identified as $N$. gypsea were indeed $N$. fulva according to ITS sequencing $[10,12]$. Soil sampling from the cities in the current study led to a similar finding. However, Pakshir et al. found both $N$. gypsea $(80 \%)$ and N. fulva (20\%) among the keratinophilic fungi isolated from soils in Shiraz City, Fars Province, southwest of Iran [14], while all isolates from Fars Province in this study were N. fulva and from a city (Noorabad) other than Shiraz. This means that the species arrangement of dermatophytes in the soils of the locations within a province can be different. While members of the N. gypsea complex were the dominant species in the soils from different localities in Iran, species other than this complex were more distinguished in the soils from some European countries. In five different reports from 1992 to 2013, T. ajelloi (currently, A. uncinatum) was the most commonly isolated species from soils in Italy, Poland, Austria and Slovakia [21-25]. Such differences in species domination can be justified with differences in the types of soils sampled. In our study, the majority of isolates were recovered from the soils of animal habitats (34\%) and parks and gardens $(32 \%)$ (which were normally inhabited by cats and dogs). This finding is consistent with the fact that $N$. gypsea and N. fulva found universally humus-rich soils or soils inhabited by heavy animal populations that provided a remarkable content of organic matter for these keratinophilic fungi $[25,26]$. The low occurrence of A. quadrifidum, A. gertleri, A. tuberculatum and other species of the genus Arthroderma in previous reports may be due to the misidentification of other non-dermatophyte species. However, in this investigation, all the isolates were identified to the species level by sequence-based procedures, and thus, the infrequency of the mentioned species can possibly be attributed to the fact that these species are weaker soil competitors than the species of the genera Nannizzia, Microsporum and Trichophyton.

A review of the literature indicates that investigations on soil-inhabitant dermatophytes have infrequently been focused on the impact of the soil $\mathrm{pH}$, place of sampling (availability of keratin materials) and, also, seasonality existence on the recovery rate of distinct dermatophyte species (Table 3). Some studies pointed out that soils with nutrients at alkaline $\mathrm{pH}$ (range 7.0-8.0) enhance the keratinolytic activity and survival of dermatophytes $[7,10,14,23,27,28]$. In the studies of Pakshir et al. and Rezaei-Matehkolaei et al., from Shiraz and Ahvaz, N. fulva and N. gypsea isolates were recovered from soils with a $\mathrm{pH}$ range of 7.0-8.0 [10,14]. In agreement with these findings, 254 out of the 256 isolates identified in the present survey, were recovered from soils with acidity ranging from 7.1 to 9.0 (Table 1). Nevertheless, among the two most abundant species, the recovery rate of N. gypsea $(82.3 \%)$ in soils with pH 7.1-8.0 was higher than that of N. fulva $(54.2 \%)$, which was statistically significant. While $A$. uncinatum is also a geophilic species known to be most frequently isolated from humus-rich soils, the infrequency of this species in the current survey can be attributed to the low degree of acidity in most soils samples from Iran $(\mathrm{pH} \geq 7)$. Statistically substantiated studies from Europe $[21,22,24,25]$ have reported that A. uncinatum in an exceptionally acidophilic species that is less-abundantly isolated from soils with $\mathrm{pH}>6.0$. In different inquiries from Iran [10,12,14], Tunisia [29] India [1,2,30], Saudi Arabia [7], the USA [18] and Brazil [27], the dermatophytes were isolated from a wide variety of soils, especially from shady and wet places rich in organic substances, e.g., gardens, public grasslands, sludge and cultivated fields, or locations with a high animal keratin content. Conversely, salty soils, waterless and beach sands and soil specimens from fruitless roadsides proved to be poor resorts for keratinophilic fungi. Concomitant with these facts, in our study, the source of the soil sample had a statistically significant effect $(p<0.05)$ on the isolation of distinct species, so that $N$. fulva was more isolated from animal habitats, parks and gardens, while N. gypsea was more recovered from the soils of home ranges and schools. In view of the geographic distribution, as illustrated in Figure 1, the isolation rate of the dermatophytes was evidently higher in Mazandaran than in the other 
provinces. In addition to $N$. fulva, the maximum isolation rate of $N$. gypsea from the soils of this province ( $91 \%$ of all the isolates) was also geo-statistically significant.

In view of the seasonality dependence, there are very rare data on whether or not dermatophytes have seasonal patterns in their soil occurrences. In our previous study from Ahvaz, southwest of Iran, the dermatophytes were statistically more recovered from soils collected in the autumn than in the spring $(p<0.05)$. Ahvaz, the capital of Khuzestan, is known for its semi-desert climate different from most parts of the country, with long and hot summers and short winters [10]. In the present study, the extension of the assessment to cities from 11 additional provinces with different climatic conditions led to a statistically significant difference $(p<0.05)$ in the recovery rate of the two dominant species, meaning was more frequently isolated in spring $(85.3 \%)$, while $N$. fulva was equally detected whatever the season. Then, the isolation of $N$. gypsea was shown to be affected by both the location and climate. The isolation of A. quadrifidum, A. tuberculatum and A. gertleri had less clinical significance, but their isolation had epidemiological implications, because the species were reported for the first time in Iran.

\section{Conclusions}

In conclusion, geophilic dermatophytes do occur in various soils from different parts and climates of Iran. The predominance of N. fulva over the others was a noticeable finding, and the species is likely the main dermatophyte species recycling of keratinous materials in the soil of the country. All the species observed in this study have been incriminated in human and animal infections and, thus, have to be accurately separated from other nonpathogenic fungi. For the definite identification of soil-inhabitant dermatophytes, DNA-based identification is strongly recommended.

Author Contributions: A.R.-M.: conceptualization, formal analysis of the data, original draft preparation, project administration and funding. K.M.: scientific advice. S.T.: performing the experiments and formal analysis of the data. S.T., M.A., F.P., E.A., M.R.J., H.Z., S.N.-S., R.M., B.A., S.A., F.K., F.N., M.D., M.N. and A.R.-M. contributed to the data collection. All authors read and agreed to the published version of the manuscript.

Funding: Ali Rezaei-Matehkolaei was funded by the Vice-Chancellor for Research Affairs of Ahvaz Jundishapur University of Medical Sciences, Ahvaz, Iran (Grant No: OG-94162).

Institutional Review Board Statement: Not applicable.

Informed Consent Statement: Not applicable.

Data Availability Statement: All relevant data are within the manuscript. More supplementary data are available on request.

Conflicts of Interest: The authors declare that they have no conflicts of interest.

\section{References}

1. Balajee, S.; Ranganathan, S.; Menon, T. Soil dermatophytes in Madras, India, in relation to human ringworm. Mycoses 1997, 40, 317-320. [CrossRef] [PubMed]

2. Jain, N.; Sharma, M. Distribution of dermatophytes and other related fungi in Jaipur city, with particular reference to soil pH. Mycoses 2011, 54, 52-58. [CrossRef]

3. De Hoog, G.S.; Dukik, K.; Monod, M.; Packeu, A.; Stubbe, D.; Hendrickx, M.; Kupsch, C.; Stielow, J.B.; Freeke, J.; Göker, M. Toward a novel multilocus phylogenetic taxonomy for the dermatophytes. Mycopathologia 2017, 182, 5-31. [CrossRef] [PubMed]

4. Weitzman, I.; Summerbell, R.C. The dermatophytes. Clin. Microbiol. Rev. 1995, 8, 240-259. [CrossRef] [PubMed]

5. Dolenc-Voljč, M.; Gasparič, J. Human infections with Microsporum gypseum complex (Nannizzia gypsea) in Slovenia. Mycopathologia 2017, 182, 1069-1075. [CrossRef]

6. Lee, W.J.; Park, J.H.; Kim, J.Y.; Jang, Y.H.; Lee, S.-J.; Bang, Y.J.; Jun, J.B. Low But Continuous Occurrence of Microsporum gypseum Infection in the Study on 198 Cases in South Korea from 1979 to 2016. Ann. Dermatol. 2018, 30, 427-431. [CrossRef] [PubMed]

7. Rizwana, H.; Abdulaziz Al Hazzani, A.; Siddiqui, I. Prevalence of dermatophytes and other keratinophilic fungi from soils of public parks and playgrounds of Riyadh, Saudi Arabia. J. Anim. Plant. Sci. 2012, 22, 948-953.

8. Vanbreuseghem, R. Technique biologique pour l'isolement des dermatophytes du sol. Ann. Soc. Belg. Med. Trop. 1952, 32, 173-178. 
9. Anderson, I.C.; Cairney, J.W. Diversity and ecology of soil fungal communities: Increased understanding through the application of molecular techniques. Environ. Microbiol. 2004, 6, 769-779. [CrossRef]

10. Rezaei-Matehkolaei, A.; Jahangiri, A.; Mahmoudabadi, A.Z.; Najafzadeh, M.J.; Nouripour-Sisakht, S.; Makimura, K. Morphomolecular characterization of soil inhabitant dermatophytes from Ahvaz, Southwest of Iran, a high occurrence of Microsporum fulvum. Mycopathologia 2017, 182, 691-699. [CrossRef]

11. Shadzi, S.; Chadeganipour, M.; Alimoradi, M. Isolation of keratinophilic fungi from elementary schools and public parks in Isfahan, Iran. Mycoses 2002, 45, 496-499. [CrossRef]

12. Dehghan, P.; Jalali, S.Y.; Chadeganipour, M. Frequency Distribution of Keratinophilic Dermatophyte Fungi from the Soil of Different Zones in Isfahan Using Morphological and Molecular Methods. Adv. Biomed. Res. 2019, 8, 38. [CrossRef]

13. Kachuei, R.; Emami, M.; Naeimi, B.; Diba, K. Isolation of keratinophilic fungi from soil in Isfahan province, Iran. J. Mycol. Med. 2012, 22, 8-13. [CrossRef]

14. Pakshir, K.; Rahimi Ghiasi, M.; Zomorodian, K.; Gharavi, A.R. Isolation and molecular identification of keratinophilic fungi from public parks soil in Shiraz, Iran. BioMed Res. Int. 2013. [CrossRef]

15. White, T.J.; Bruns, T.; Lee, S.; Taylor, J. Amplification and direct sequencing of fungal ribosomal RNA genes for phylogenetics. In PCR protocols: A Guide to Methods and Applications; Academic Press: Cambridge, MA, USA, 1990; Volume 18, pp. 315-322.

16. Rezaei-Matehkolaei, A.; Makimura, K.; Shidfar, M.; Zaini, F.; Eshraghian, M.; Jalalizand, N.; Nouripour-Sisakht, S.; Hosseinpour, L.; Mirhendi, H. Use of single-enzyme PCR-restriction digestion barcode targeting the internal transcribed spacers (ITS rDNA) to identify dermatophyte species. Iran. J. Public Health 2012, 41, 82.

17. Sharma, R.; Presber, W.; Rajak, R.C.; Gräser, Y. Molecular detection of Microsporum persicolor in soil suggesting widespread dispersal in central India. Med. Mycol. 2008, 46, 67-73. [CrossRef]

18. Giugnani, H.C.; Venketesan, K. Dermatophytes and Other Keratinophiic Fungi in Soils of Anguilla, British West Indies (BWI). Microbiol. Res. J. Int. 2020, 30, 1-6. [CrossRef]

19. Gugnani, H.C.; Sharma, S.; Gupta, B.; Gaddam, S. Prevalence of keratinophilic fungi in soils of St. Kitts and Nevis. J. Infect. Dev. Ctries 2012, 6, 347-351. [CrossRef]

20. Taha, M.; Tartor, Y.H.; Abdallah, S.A.; Osman, M.M.; Ammar, A.M. Diversity of Arthrodermataceae Communities That Create Havoc to the Overall Health of Human and Animals. Slov. Vet. Res. 2018, 55, 73-84.

21. Caretta, G.; Mangiarotti, A.; Piontelli, E. Keratinophilic fungi isolated from soil of Italian parks in the province of Pavia. Eur. J. Epidemiol. 1992, 8, 330-339. [CrossRef]

22. Ciesielska, A.; Bohacz, J.; Korniłłowicz-Kowalska, T.; Staczek, P. Microsatellite-Primed PCR for Intra-species Genetic Relatedness in Trichophyton ajelloi Strains Isolated in Poland from Various Soil Samples. Microb. Environ. 2014, 29, 178-183. [CrossRef]

23. Kačinová, J.; Tančinová, D.; Labuda, R. Keratinophilic fungi in soils stressed by occurrence of animals. J. Microbiol. Biotechnol. Food Sci. 2021, 2021, 1436-1446.

24. Javoreková, S.; Labuda, R.; Maková, J.; Novák, J.; Medo, J.; Majerčíková, K. Keratinophilic fungi isolated from soils of long-term fold-grazed, degraded pastures in national parks of Slovakia. Mycopathologia 2012, 174, 239-245. [CrossRef]

25. Bohacz, J.; Korniłłowicz-Kowalska, T. Species diversity of keratinophilic fungi in various soil types. Cent. Eur. J. Biol. 2012, 7, 259-266. [CrossRef]

26. Papini, R.; Mancianti, F.; Grassotti, G.; Cardini, G. Survey of keratinophilic fungi isolated from city park soils of Pisa, Italy. Mycopathologia 1998, 143, 17-23. [CrossRef]

27. Pontes, Z.D.S.; Oliveira, A. Dermatophytes from urban soils in João Pessoa, Paraíba, Brazil. Rev. Argent. Microbiol. 2008, 40, 161-163.

28. Sharma, A.; Chandra, S.; Sharma, M. Difference in keratinase activity of dermatophytes at different environmental conditions is an attribute of adaptation to parasitism. Mycoses 2012, 55, 410-415. [CrossRef]

29. Anane, S.; Al-Yasiri, M.H.Y.; Normand, A.-C.; Ranque, S. Distribution of keratinophilic fungi in soil across Tunisia: A descriptive study and review of the literature. Mycopathologia 2015, 180, 61-68. [CrossRef]

30. Randhawa, H.u.; Sandhu, R. A survey of soil inhabiting dermatophytes and related keratinophilic fungi of India. Sabouraudia J. Med. Vet. Mycol. 1965, 4, 71-79. [CrossRef] 